\title{
Application of Multivariate Approaches to the Hydro-chemical Assessment of the Ghodaghodi Lake, Sudurpaschim Province, Nepal
}

\author{
Ramesh Raj Pant ${ }^{1}$, Khadka Bahadur Pal ${ }^{2}$, Kiran Bishwakarma ${ }^{3,4 *}$, Lal B Thapa ${ }^{5}$, Alina Dangol ${ }^{1}$, \\ Binod Dawadi ${ }^{6}$, Pramod Poudel ${ }^{7}$, Binod Bhattarai ${ }^{7}$, Tarka Raj Joshi ${ }^{8}$, and Youb Raj Bhatt ${ }^{1}$ \\ ${ }^{1}$ Central Department of Environmental Science, Institute of Science and Technology, Tribhuvan University, \\ Kathmandu, Nepal \\ ${ }^{2}$ Tri-Chandra Multiple Campus, Tribhuvan University Kathmandu, Nepal \\ ${ }^{3}$ Institute of Tibetan Plateau Research, Chinese Academy of Sciences, Beijing 100101, China \\ ${ }^{4}$ University of Chinese Academy of Sciences, Beijing 100049, China \\ ${ }^{5}$ Central Department of Botany, Institute of Science and Technology, Tribhuvan University, Kathmandu, Nepal \\ ${ }^{6}$ Central Department of Hydrology and Meteorology, Institute of Science and Technology, \\ Tribhuvan University, Kathmandu, Nepal. ${ }^{7}$ University Grants Commission, Nepal \\ ${ }^{8}$ Faculty of Science and Technology, Far-western University, Kanchanpur, Nepal
}

\section{*CORRESPONDENCE:}

\section{Kiran Bishwakarma}

Institute of Tibetan Plateau Research, Chinese Academy of Sciences, Beijing 100101, China University of Chinese Academy of Sciences, Beijing 100049, China

Email: kiranghatani11@gmail.com

ISSN : 2382-5359(Online), 1994-1412(Print)

DOI:

https://doi.org/10.3126/njst.v20i1.39434

ACCESS THE ARTICLE ONLINE

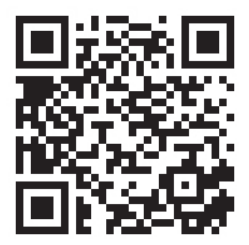

\section{CONFILICT OF INTEREST: None}

Copyright: The Author(s) 2020. This is an open

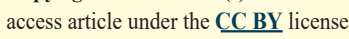

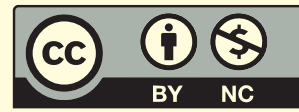

\begin{abstract}
Wetlands are considered the most diverse and productive ecosystems in the world, providing life-sustaining ecological services. Hydrochemical variables of the Ghodaghodi Lake situated in Far west Nepal were studied using multivariate statistical approaches to investigate the characteristics of water quality of the lake. A total of 10 water samples were collected and analyzed for water temperature, $\mathrm{pH}$, electrical conductivity, total dissolved solids, total hardness, salinity, dissolved oxygen, major ions, and dissolved $\mathrm{Si}$ in the pre-monsoon season during 2017. The water quality assessment was carried out by applying sodium percentage, sodium adsorption ratio, permeability index, Kelly's ratio, magnesium adsorption ratio, action ratio of soil structural stability, and water quality index. Multivariate statistical techniques were used to evaluate the geochemical and anthropogenic processes and to identify factors influencing the ionic concentrations. The results revealed that the water was slightly alkaline with low ionic strength and remarkable spatial variations. The hydrochemistry of the lake was mainly controlled by rock weathering as the dominant $\mathrm{Ca}^{2+}-\mathrm{HCO}_{3-}$ facies. The principal component analysis provided three major components exhibiting the diverse sources of natural and anthropogenic chemicals, including agricultural fertilizers, leakage of sewages near the human settlements, etc. The measured hydrochemical parameters indicate that lake water lies within the safe drinking water and irrigational standards. However, special consideration should be taken to control the concentrations of $\mathrm{NO}_{3-}$ due to increasing anthropic activities. Keywords: Hydrochemistry, statistical analysis, water quality
\end{abstract}




\section{INTRODUCTION}

Wetlands are one of the primary and most trusted sources of freshwater in the world (Khadka \& Ramanathan 2013). The wetland ecosystems are the most diverse, providing lifesustaining ecological services and economic values (Pant \& Adhikari 2015). Water purification, nutrient retention, groundwater recharge, biodiversity conservation, food supply, etc., are critical functions directly associated with the wetland ecosystem (Singh et al. 2016) However, during the last few decades, productive wetland eco system suffer from intense anthropogenic pressure(Pant et al. 2019a). The most important natural surface processes that regulate freshwater bodies' hydrochemistry include precipitation, geochemical weathering, recharge and discharge, ion exchange and redox reactions, and evapo-crystallization (Gibbs 1970). Anthropogenic activities, including leaching of fertilizers from farmlands, industrial effluents, and domestic wastes, can also affect water quality in the lakes (Pant et al. 2019).

The freshwater hydrochemistry describes the interactions between exogenic and endogenic processes, the behavior of dissolved chemical variables, and watershed characteristics. The freshwater lakes constitute a unique geochemical process as they are less dynamic and more susceptible to both natural and anthropic interventions (Rupakheti et al. 2017). The chemical quality of the lakes has been widely controlled by weathering of underlying rocks, evapo-crystallization, and atmospheric precipitation in the natural conditions whereas, the anthropic inputs such as urban runoff, industrial effluents, and land use/cover change are the major sources of contaminants (Pant et al. 2018). In addition, global climate change has further aggravated the impacts on the quality and the quantity of the water resources, hence the study of freshwater quality has immense significance for the sustainability of human society and ecosystems.

Multivariate statistical analysis and geochemical indices are widely used to evaluate the hydrochemistry and pollution levels of the water bodies (Pant et al. 2018). Pollution in the wetland ecosystem is common in developing and developed countries and one of the serious environmental issues under global climate change. The chemical contamination in freshwater bodies is one of the severe issues from the Himalayas, especially from human consumption, irrigation, industrial and other purposes (Sharma et al. 2020; Pal et al. 2021). The contamination of freshwater bodies can result in low drinking and irrigation water quality and cause potential human and ecological health problems. In general, the fluctuation in the parameters, including ionic constituents in water beyond the permissible level due to various natural and anthropogenic processes (Pal et al. 2019; Pant et al. 2021a)
Although Nepal is rich in freshwater resources, the Ramsar sites and other freshwater lakes are under high pressure due to various anthropogenic activities and global climate change (Zhang et al. 2019). Overdependence on the water to meet the ever-increasing demands of domestic, agricultural, industrial, and haphazard developmental activities has resulted in the overexploitation of water resources and deteriorated lake water quality in Nepal (Rupakheti et al. 2017). Several studies were conducted in different parts of the country to evaluate the water quality and its suitability for various purposes, spatiotemporal distribution, surface water interactions, and water vulnerability (Khadka \& Ramanathan 2013; Pal et al. 2019; Bishwakarma et al. 2019; Pant et al. 2013; Pant et al. 2018; Sharma et al. 2020; Pant et al. 2021b). These studies have highlighted the anthropogenic pressures from agricultural lands, urban and domestic sewage discharge, and the elevated chemical attributes pose safety apprehensions for drinking and irrigation purposes of freshwater bodies of Nepal when compared to WHO, US EPA, FAO, and other standard guidelines of water quality (WHO 2011).

Ghodaghodi Lake is one of the Ramsar listed (Ramsar site No. 1314) wetlands and the famous tourist destinations in the Sudurpashim Province, Nepal. The lake supports the livelihoods of local communities and is a staging area for migrating birds. Studies with regard to Ghodaghodi Lake Area is scattered and there are limited studies for the quality assessment of the current status of the lake. In this study, the multivariate statistical approaches, combined with geochemical indices, were adopted to characterize the water quality of the Ghodaghodi Lake. The findings of this study could be useful for Provincial and Local government and relevant stakeholders working in the area for the sustainable management of the Ghodaghodi Lake as an Important Ramsar sites of Nepal.

\section{MATERIALS AND METHODS}

\subsection{Study Area}

Ghodaghodi Lake is enlisted as Ramsar site as one of the largest inter-connected natural lake systems in Nepal's Terai region. It is located at the latitude of $28^{\circ} 41^{\prime} 17^{\prime \prime} \mathrm{N}$ and the longitude of $80^{\circ} 56^{\prime} 47^{\prime \prime} \mathrm{E}$ at $205 \mathrm{~m}$ above sea level in the Ghodaghodi Municipality of Kailali District, Sudurpaschim Province, Nepal (Fig. 1). The maximum length of the lake is $1.83 \mathrm{~km}$ and the average depth of lake is about $4 \mathrm{~m}$. Three small settlements surround the study area: Sandepani, Darakh, and Ramshikharjhala in the east, south, and northwest, respectively, and approximately covers an area of 2500ha. It has 14 large and small oxbow lakes, including main Ghodaghodi (138ha), Nakharodi (70ha), and 
Baishawa (10ha), and are associated with marshes, swamps, streams, and springs, together with canals, irrigated fields, and ponds (Bhatta et al. 2020). The area is also surrounded by tropical deciduous mixed Salforest (Shorearobusta) in the Siwalik Hills' lower slopes. The lake system located inside the Basanta Protection Forests and is a biological corridor for mega fauna, the corridor connecting Bardia National Park in the east and Suklaphanta National Park in the west. The lake experiences a tropical monsoon climate, dry winter, and rainy summer. The maximum temperature of this area ranges from $22^{\circ} \mathrm{C}$ to $37^{\circ} \mathrm{C}$ and minimum from $5^{\circ} \mathrm{C}$ to $25^{\circ} \mathrm{C}$. The average annual rainfall ranges between $1630 \mathrm{~mm}$ and $1705 \mathrm{~mm}$, where about $80-85 \%$ of the total rainfall occurs during the monsoon season from June to late September (Lamsal et al. 2014).

\subsection{Sample Collection and Analysis}

The field work of this study was conducted in March 2017, and the sampling was carried out to allow maximum representativeness of the lake. The water samples were collected from 10 different sites of the lake (Fig.1). The representative samples were taken from the periphery and center on the basis of potential pollution sources, land use pattern of the surrounding areas, and disturbed and relatively less disturbed site. Water temperature, $\mathrm{pH}, \mathrm{EC}$, and TDS were measured on-site using a multi-purpose probe (YSI 6920). Besides, DO and salinity was also measured in-situ using the DO and salinity meters. For the collection of the samples, previously acid-washed 1L highdensity polyethylene bottles were used.

All the samples were filtered through $0.45 \mu$ mmillipore nitrocellulose paper, and a small portion of samples was collected for measuring $\mathrm{Cl}^{-}, \mathrm{NO}_{3}{ }^{-}$and $\mathrm{SO}_{4}{ }^{2-}$ concentrations, while the remaining portion was acidified with ultra-pure $\mathrm{HNO}_{3}$ to reduce the $\mathrm{pH}<2$ for $\mathrm{Na}^{+}, \mathrm{K}^{+}, \mathrm{Ca}^{2+}, \mathrm{Mg}^{2+}$ and $\mathrm{Si}$ determination as described by (APHA, 2005). During the laboratory analyses, distilled deionized water was used, and freshly prepared standards of known concentrations and procedural blanks were analyzed during each analytical run, and no detectable contaminations were found. Furthermore, each calibration curve was evaluated by analyses of a set of samples. The data for this study was collected for only one time which is one of the limitations of the study.

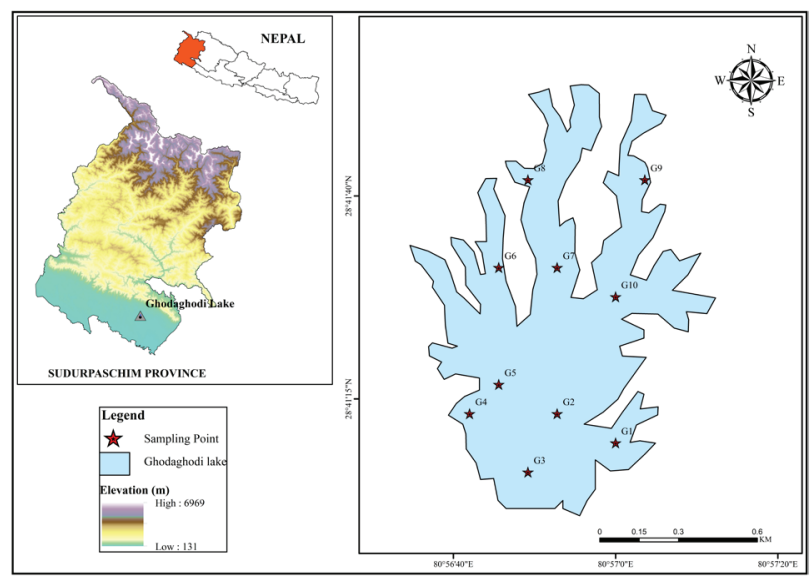

Fig. 1. Sampling locations in the Ghodaghodi Lake, Sudurpaschim Province, Nepal

\subsection{HYDROCHEMICAL ANALYSIS}

The study has intensively examined the major physicochemical parameters of both the on-site and laboratory as per the standard methods (APHA 2005). Proper care was taken to make the container neat and clean, avoiding impurities' effects in the results before sampling. A total of 16 parameters were analyzed, including significant cations and anions. Water temperature, $\mathrm{pH}$, electrical conductivity (EC), salinity (SA), and total dissolved solids (TDS) were measured at the sampling site using a YSI 6920. The dissolved oxygen (DO) was determined by $\mathrm{DO}$ meter on the spot, and the total $\mathrm{HCO}_{3}$ - was determined by titration with $\mathrm{HCl}$ on the same day. Major cations $\left(\mathrm{Na}^{+}, \mathrm{K}^{+}, \mathrm{Ca}^{2+}\right.$ and $\left.\mathrm{Mg}^{2+}\right)$ and $\mathrm{Si}$ were determined using Inductively Coupled Plasma Optical Emission Spectrometer (ICP-OES, Prodigy). Anions $\left(\mathrm{Cl}^{-}, \mathrm{NO}_{3}^{-}\right.$, and $\mathrm{SO}_{4}{ }^{2-}$ ) were measured using an Ion Chromatography of Dionex (ICS 900, USA) and all the laboratory analysis was conducted at the Institute of Tibetan Plateau Research, Chinese Academy of Sciences (ITP-CAS), Beijing, China. Each calibration curve was evaluated by analyzing quality control standards before, during, and after the samples' analysis. Geochemical characterization of water quality in the lake was assessed by the Piper (1944) diagram, whereas Gibbs (1970) plots did the controlling mechanisms of natural water quality.

\subsection{Irrigation Suitability Assessment}

The chemical and physical characteristics of the lake water are the fundamental consideration for the irrigation water quality evaluation. The specific hydrochemical parameters such as $\mathrm{EC}, \mathrm{HCO}_{3}^{-}, \mathrm{Ca}^{2+}, \mathrm{Mg}^{2+}, \mathrm{Na}^{+}$, and $\mathrm{K}^{+}$are considered 
to analyze irrigation water quality. Such properties have relevant relation to the growth and productivity of crops. The irrigation water quality of different sections in the Ghodaghodi Lake has been applying EC, sodium percentage $(\mathrm{Na} \%)$, sodium adsorption ratio (SAR), magnesium adsorption ratio (MAR), Kelly's ratio (KR), permeability index (PI), cation ratio of soil structural stability (CROSS), and Wilcox diagram. Also, the lake's drinking water quality was evaluated using a water quality index (WQI). The detailed methodologies for irrigational quality assessment are explained elsewhere (Acharya et al. 2020).

\subsection{Data Analysis}

Principal component analysis (PCA) is one of the most important multivariate statistical tool, identifying the various processes that control the solute concentrations (Singh et al. 2004; Filzmoser et al. 2009). PCA was computed for the EC, TDS, $\mathrm{Ca}^{2+}, \mathrm{Mg}^{2+}, \mathrm{Na}^{+}, \mathrm{K}^{+}, \mathrm{Si}, \mathrm{Cl}^{-}$, $\mathrm{NO}_{3}^{-}, \mathrm{SO}_{4}^{2-}$ and $\mathrm{HCO}_{3}^{-}$to identify the sources of different hydrochemical parameters. The KMO-test was carried out to examine the data set's suitability, and factor loadings were determined after plotting the screen plot. The extraction factors were based on the variances and covariance of the variables. The factor with eigen values $>1$ is considered as the significant variable in this study. Finally, by the process of rotation, each variable's loading on one of the extracted factors is maximized, and the loadings of all the other factors are minimized. For the statistical analysis, the software package (SPSS 26) was used (Sajil Kumar 2016).

\section{RESULTS AND DISCUSSION}

\subsection{General Hydrochemistry and Spatial Distribution}

A descriptive statistical summary of major hydrochemical compositions of the Ghodaghodi Lake is presented in Table 1.The lake water was mildly alkaline, $\mathrm{pH}$ ranging from 7.11 to 8.80 with a mean value of $7.96 \pm 1.54$. The lake's dissolved oxygen (DO) was observed between 3.14 $\mathrm{mg} / \mathrm{L}$ to $7.41 \mathrm{mg} / \mathrm{L}$, with a mean value of $5.54 \mathrm{mg} / \mathrm{L} \pm 1.35$ $\mathrm{mg} / \mathrm{L}$, indicating the aquatic species can survive in the lake (Gautam et al. 2015). Lake water has low TDS, ranges between 63 to $98 \mathrm{mg} / \mathrm{L}$, and low mineralization, as shown by the EC measurements, varying from 112 to $182 \mu \mathrm{S} / \mathrm{cm}$. $\mathrm{Ca}^{2+}$ and $\mathrm{Na}^{+}$are the most abundant cations with average concentrations of $13.96 \mathrm{mg} / \mathrm{L}$ to $17.11 \mathrm{mg} / \mathrm{Land} 4.24 \mathrm{mg} / \mathrm{L}$ to $9.26 \mathrm{mg} / \mathrm{L}$, respectively. $\mathrm{K}^{+}$is the least abundant major cation with an average concentration of $1.46 \mathrm{mg} / \mathrm{L}$ to 3.09 $\mathrm{mg} / \mathrm{L}$. The cationic dominance was found in the order of $\mathrm{Ca}^{2+}>\mathrm{Na}^{+}>\mathrm{Mg}^{2+}>\mathrm{K}^{+}$.

$\mathrm{HCO}_{3}$-is the most abundant major anion, ranged from $35 \mathrm{mg} / \mathrm{L}$ to $65 \mathrm{mg} / \mathrm{L}$. The second most abundant anion is $\mathrm{SO}_{4}^{2-}$ ranging from $3.25 \mathrm{mg} / \mathrm{L}$ to $6.03 \mathrm{mg} / \mathrm{L}$. The order of the dominance of anions is $\mathrm{HCO}_{3}>\mathrm{SO}_{4}{ }^{2-}>\mathrm{Cl}^{-}>\mathrm{NO}_{3}$. Dissolved silica has a lower concentration with a mean value of $1.08 \mathrm{mg} / \mathrm{L}$. Among the major ions, the highest mean concentration was found for the $\mathrm{HCO}_{3}^{-}$. By comparing with the World Health Organization (WHO 2011) for drinking water (Table 1), all the hydro-chemical variables are within the permissible limits for drinking water in the Ghodaghodi Lake. Also, excessive loading of $\mathrm{NO}_{3}{ }^{-}$contributes to Lake Eutrophication. The mean value of $\mathrm{NO}_{3}^{-}$is $>2 \mathrm{mg} / \mathrm{L}$. Thus, there is an indication of possible enrichment of $\mathrm{NO}_{3}^{-}$but it is still within the permissible drinking water limits.

The distinct spatial variations were observed in the mean concentrations of measured hydrochemical variables in the Ghodaghodi Lake (Fig. 2). For instance, the pH, EC, TDS, $\mathrm{Ca}^{2+}, \mathrm{Mg}^{2+}$, and $\mathrm{HCO}_{3}^{-}$were relatively higher in the outlet sections of the lake (i.e. sampling No. G1 to G5, Fig. 1). On the other hand, the mean concentration of dissolved Si and $\mathrm{SO}_{4}^{2-}$ were relatively higher in the inlet section of the lake. Interestingly, some of the sampling locations such as G1 and G6 are characterized by the elevated concentration of the $\mathrm{K}^{+}$. Whereas, $\mathrm{NO}_{3}^{-}$was markedly higher in the G10. The spatial variations of hydrochemical parameters indicated that both the point and non-points sources of pollution are prevalent in the lake basin. Meanwhile, the inlet section of the lake basin is relatively less contaminated as compared to the outlet section except for $\mathrm{G} 10$ for $\mathrm{NO}_{3}^{-}$. In the proximity of $\mathrm{G} 10$, intense farming has been existing thus the major sources of the NO3-could be agricultural activities. Finally, the outlets' section (G1) is characterized by the elevated concentration of most of the chemical variables which could be due to the anthropic activities in the nearby settlements.

Table 1: Descriptive statistics of the physicochemical composition of the Ghodaghodi Lake, Sudurpaschim Province, Nepal

\begin{tabular}{|l|l|l|l|l|l|}
\hline Parameter & Min & Max & Mean & SD & $\begin{array}{l}\text { WHO drink- } \\
\text { ing water limit }\end{array}$ \\
\hline Temp. & 30 & 34.7 & 32 & 1.54 & - \\
\hline pH & 7.1 & 8.8 & 8 & 0.64 & $6.5-8.5$ \\
\hline EC & 112 & 181 & 142 & 26.52 & 1500 \\
\hline TDS & 63 & 98 & 77 & 13.69 & 1000 \\
\hline SA & 28 & 40 & 31 & 3.52 & - \\
\hline DO & 3.2 & 7.41 & 5.5 & 1.35 & 5 \\
\hline $\mathrm{Ca}^{2+}$ & 14 & 17.11 & 16 & 1.034 & 100 \\
\hline $\mathrm{Mg}^{2+}$ & 2.3 & 2.67 & 2.4 & 0.12 & 50 \\
\hline
\end{tabular}




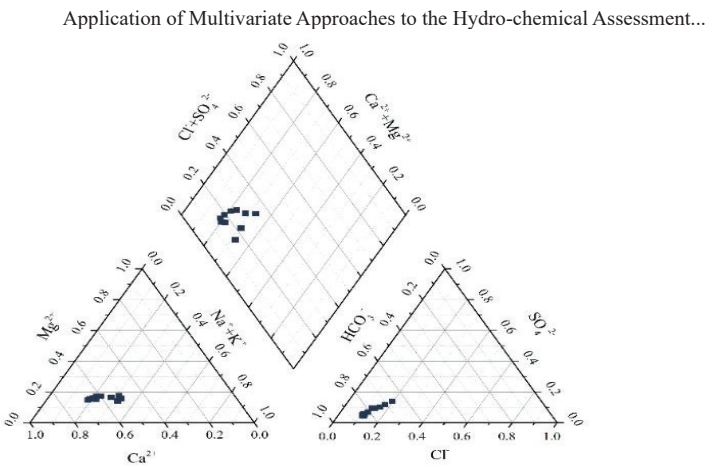

The temperature in ${ }^{\circ} \mathrm{C}$ and other concentrations are expressed in $\mathrm{mg} / \mathrm{L}$ except for $\mathrm{EC}$ in $(\mu \mathrm{S} / \mathrm{cm})$ and $\mathrm{pH}$

Fig. 3. Piper diagram showing the $\mathrm{Ca}^{2+}-\mathrm{HCO}_{3}$ hydrochemical facies of Ghodaghodi Lake, Sudurpaschim Province, Nepal
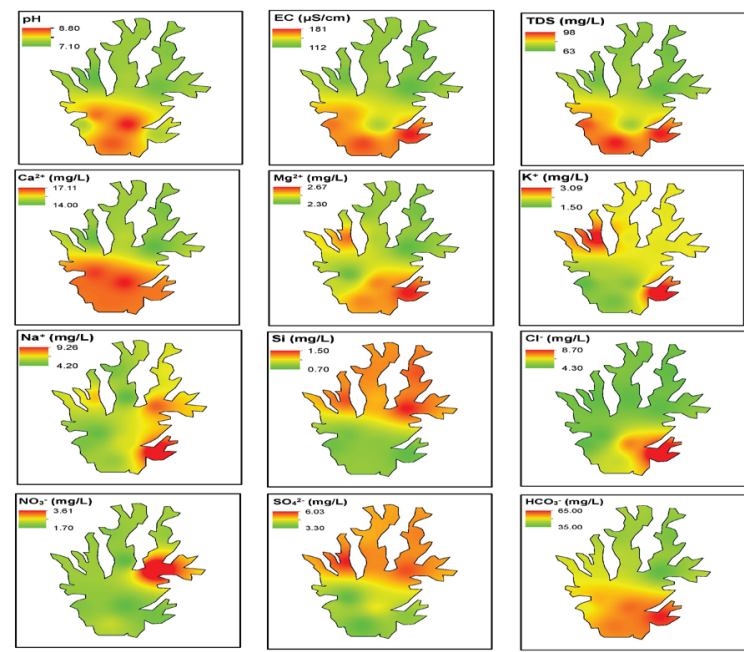

Fig. 2 Spatial variations of the physicochemical parameter in the GhodaghodiLake,Sudurpaschim Province, Nepal

\subsection{Characterisation of Hydrochemical Facies}

The lake's water type was identified through the Piper trilinear diagram (Fig. 3). The piper diagram reveals that the dominancy of a weak acid $\left(\mathrm{HCO}_{3}^{-}\right)$over strong acid $\left(\mathrm{SO}_{4}^{2-}+\mathrm{Cl}^{-}\right)$and alkaline earth metals $\left(\mathrm{Ca}^{2+}+\mathrm{Mg}^{2+}\right)$ over alkali metals $\left(\mathrm{Na}^{+}+\mathrm{K}^{+}\right)$.It shows that $\mathrm{Ca}^{2+}-\mathrm{HCO}_{3}^{-}$is the central dominant hydrochemical facies in the Ghodadhodi Lake. Major cations and anions' arrangements suggested that the freshness of these water samples with carbonate weathering as a dominant mechanism regulating the lake's hydrochemistry. The hydrochemical facies of the Ghodaghodi Lake is also comparable with the other lakes of Nepal Himalaya such as Phewa Lake, Jhilmila Lake, Begnas Lake, Rupa Lake, etc. (Pant \& Adhikari 2015, Pant et al. 2019, Adhikari et al. 2020; Pal et al. 2021). The dominancy of $\mathrm{Ca}^{2+}$ and $\mathrm{HCO}_{3}^{-}$in total cation, and anion, respectively in the Nepal Himalaya region is mainly due to the intense carbonate rock weathering (Pant et al. 2018).

\subsection{Source Appointment and Controlling Factors}

\subsubsection{Principal Component Analysis (PCA)}

Based on the 11 hydro chemical variables, PCA analysis was applied to identify the variables with the most significant explanatory power that govern the lake water's chemical composition (Adhikari et al. 2020). The results of principal components (PCs), variable loadings, and variance are presented in Fig. 4. The highest eigen values are the most significant, and eigen values $>1$ are considered significant (Li \& Zhang 2010). The component loadings are 'strong' and 'moderate,' corresponding to absolute loading values of $>0.75$ and $0.75-0.50$. Three powerful PCs have observed eigen value $>1.0$ in this study.

The PC1accountsfor $56.88 \%$ of total variance with strongly favorable loading on $\mathrm{EC}$, TDS, $\mathrm{Ca}^{2+}$, and $\mathrm{HCO}_{3}$; moderate positive loadings on $\mathrm{Cl}^{\text {- }}$, whereas strong negative loadings on $\mathrm{Si}$ and $\mathrm{SO}_{4}{ }^{2-}$. The possible sources of constituents in $\mathrm{PC} 1$ are natural ones, mainly derived from carbonate rocks' weathering. PC2 is responsible for $23.59 \%$ of total variance with strong positive loadings on $\mathrm{K}^{+}$and $\mathrm{Na}^{+}$and moderate positive loadings on $\mathrm{Mg}^{2+}$ and $\mathrm{Cl}^{-}$, suggesting the silicate weathering. PC3 accounts for $9.77 \%$ of total variance with strong loadings on $\mathrm{NO}_{3}^{-}$. The contamination of $\mathrm{NO}_{3}{ }_{3}^{-}$in lake water mainly from anthropogenic activitiesis one of this study's key findings. Most of the lake's area vicinity is used for agricultural and religious purpose. Excessive use of fertilizers and organic chemicals could be the $\mathrm{NO}_{3}^{-}$sources in the lake water. Also, $\mathrm{NO}_{3}^{-}$in the surface water is contributed from the decomposition of soil organic matter, leaching of nitrogen-containing chemical fertilizers, and animal excreta. The results revealed that the sampling points nearby the settlements and intensive farming are relatively more contaminated as compared to the central section of the lake. These results are consistent with the spatial variations (Fig. 2) as it was observed that the diverse sources of natural and anthropogenic chemicals, including agricultural fertilizers, leakage of sewages near the human settlements, etc. could be the major sources of contamination. 


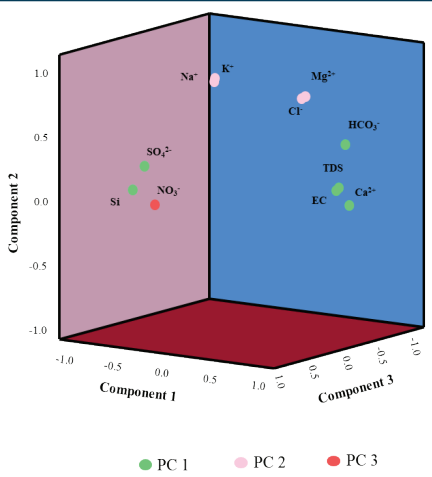

Fig. 4. Factor loading plot of the principal component analysis for EC, TDS, and major ions

in the Ghodaghodi Lake, Sudurpaschim Province, Nepal

\subsubsection{Gibbs Plots}

The lake's chemical substances have multiple sources, such as weathering of carbonate, silicate, evaporites (the chemicals including sodium salts, and halite that crystallizes from evaporating lake water), and sulfide minerals, including anthropogenic contributions and cyclic salts (Varol et al. 2013). Gibbs (1970) provided a simple plot of TDS versus the weight ratio of $\mathrm{Na}^{+} /\left(\mathrm{Na}^{+}+\mathrm{Ca}^{2+}\right)$ and $\mathrm{Cl}^{-} /\left(\mathrm{Cl}^{-}+\mathrm{HCO}_{3}^{-}\right)$to determine the relative importance of three major-natural mechanisms including atmospheric precipitation, evapo-crystallization, and rock weathering that control the surface lake water chemistry. The TDS concentration and the weight ratios of $\mathrm{Na}^{+} /\left(\mathrm{Na}^{+}+\mathrm{Ca}^{2+}\right)$ and $\mathrm{Cl}^{-} /\left(\mathrm{Cl}^{-}+\mathrm{HCO}_{3}^{-}\right)$plotted for the Ghodaghodi Lake revealed that the lake water has a low ratio of $\mathrm{Na}^{+} /\left(\mathrm{Na}^{+}+\mathrm{Ca}^{2+}\right)$ and $\mathrm{Cl}^{-} /\left(\mathrm{Cl}^{-}+\mathrm{HCO}_{3}{ }^{-}\right)$, and moderate TDS concentrations (Fig. 5). It has indicated the domination of rock-weathering as a primary controlling mechanism in the hydrochemistry of the lake. The rock dominance in the lake basin provides insight into chemical weathering in the drainage since weathering of different parent rocks (e.g., carbonates, silicates, \& evaporites) yields different combinations of dissolved cations and anions to the lake water. For instance, $\mathrm{Ca}^{2+}$ and $\mathrm{Mg}^{2+}$ originate from the weathering of carbonates, silicates, and evaporates; $\mathrm{Na}^{+}$and $\mathrm{K}^{+}$from the weathering of evaporites and silicates; $\mathrm{HCO}_{3}^{-}$from carbonates and silicates, while $\mathrm{SO}_{4}^{2-}$ and $\mathrm{Cl}^{-}$from evaporites, and silica exclusively sources from the weathering of silicates (Chen et al. 2002). The lake's ion chemistry can also be affected by human activities (Meybeck \& Helmer 1989; Singh et al. 2016). The anthropogenic impacts have been increasing recently due to the dramatic increases in industrial, agricultural, urbanization, and domestic activities. Though major-ion compositions on the lake are within the range of natural water chemistry, the signature of elevated concentrations of $\mathrm{Cl}^{-}, \mathrm{NO}_{3}^{-}$and $\mathrm{SO}_{4}{ }^{2-}$ in the lake samples are due to anthropogenic sources. Notably, $\mathrm{NO}_{3}^{-}$has significantly higher concentrations $(>2 \mathrm{mg} / \mathrm{L})$. The results also highlight the signature of religious activities around the lake.
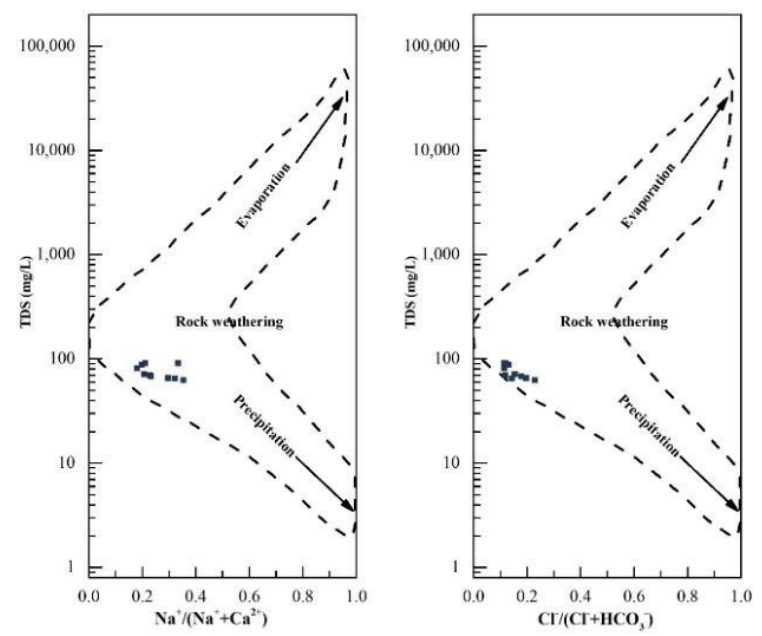

Fig. 5. Gibbs plot showing rock weathering is the primary natural controlling mechanism of hydrochemistry in the

Ghodaghodi Lake, Sudurpaschim Province, Nepal

\subsection{Water Quality for Irrigation and Drinking Purpose}

The Ghodaghodi Lake water irrigation suitability has been evaluated using different methods and presented in Table 2. EC's classification suggested that all the points are in the "Excellent" category and concluded that the lake water is acceptable for irrigation purposes. About 21,000 ha area of the Ghodaghodi Municipality is used for the agricultural purposes. The majority of the area has been irrigated by the water from the lake complex. $\mathrm{Na} \%$ in the lake ranges from $18.49 \%$ to $32.80 \%$, categorized as Good and Excellent. Additionally, the SAR values of this lake water $(<0.60)$ indicated the "Excellent" category and signify the potentiality of water for irrigation purposes. Both the MAR $(<30)$ and KR $(<0.50)$ values belong to the safe category for irrigational usage, suggesting that lake water is suitable for irrigation (Acharya et al. 2020)Nepal. In this study, the surface water samples were collected from 16 sites with a $0.5 \mathrm{~km}$ interval to characterize and evaluate the water quality mainly from the perspective of its irrigational usage. The assessment was carried out by applying electrical conductivity (EC. The PI's value was found to be $<115$ displayed the lake lies in category I, i.e., good. The CROSS values of the lake are found in the "Excellent" category. Furthermore, lake water's suitability for drinking purposes was assessed using the WQI, and found that water is suitable for drinking purposes based on measured hydro chemical variables. 
Table 2. Drinking and irrigational water quality of the Ghodaghodi Lake, Sudurpaschim Province, Nepal

\begin{tabular}{|l|l|l|}
\hline \multicolumn{1}{|c|}{ Parameter } & \multicolumn{1}{c|}{ Average Value } & \multicolumn{1}{c|}{ Category } \\
\hline WQI & 8.68 & Excellent \\
\hline EC & 142 & Excellent \\
\hline $\mathrm{Na} \%$ & 24.77 & Good \\
\hline SAR & 0.37 & Excellent \\
\hline MH & 21.35 & Suitable \\
\hline KR & 0.28 & Safe \\
\hline PI & 103.89 & Class I \\
\hline CROSS & 0.44 & Excellent \\
\hline
\end{tabular}

\section{CONCLUSION}

The study was done for hydro chemical investigation in the Ghodaghodi Lake water by applying multivariate statistical approaches and geochemical indices. The lake water was mildly alkaline with relatively low EC and TDS values. The dominance order of major cations and anions were $\mathrm{Ca}^{2+}>\mathrm{Na}^{+}>\mathrm{Mg}^{2+}>\mathrm{K}^{+}$, and $\mathrm{HCO}_{3}>\mathrm{SO}_{4}{ }^{2-}>\mathrm{Cl}^{-}>\mathrm{NO}_{3}{ }^{-}$, respectively. The characterization of hydrochemistry was carried out by plotting the Piper diagram, and only $\mathrm{Ca}^{2+}$ $\mathrm{HCO}_{3}^{-}$a type of water facies was observed, which exhibited the carbonate-dominated underlying lithology in the lake basin. From the PCA, three principal components were derived, which explained $>90 \%$ of the variations. $\mathrm{PC} 1$, PC2, and PC3 were high loadings with EC, TDS, $\mathrm{Ca}^{2+}$, and $\mathrm{HCO}_{3} ; \mathrm{K}^{+}, \mathrm{Na}^{+}$, and $\mathrm{Cl}$; and $\mathrm{NO}_{3}^{-}$indicating the geogenic, mixed, and anthropogenic sources of origin, respectively. These results are also in good agreement with Gibb plots.

While comparing the hydro chemical variables with WHO drinking water guideline values, the lake water was safe for drinking water purposes. Similarly, irrigation water quality standards indicated no severe threats in the water quality currently, however increasing concentration of the variables may pose some issues in the future. Nevertheless, special attention should be given to control the increasing concentration of $\mathrm{NO}_{3}^{-}$due to various anthropogenic stresses in the lake's vicinity. The research finding will help provide new insights into the sustainable water quality of the Ramsar listed wetlands. A further in-depth study focusing on hydro chemical variation concerning the lake's seasonality impacts is recommended for future study.

\section{ACKNOWLEDGEMENT}

The authors would like to thank Professor Dr. Zhang Fan for supporting the samples' laboratory analysis in the Institute of Tibetan Plateau Research, Chinese Academy of Sciences, China. The authors are also grateful to the Central Department of Environmental Science to support the data collection and making a conducive environment for this research work.

\section{REFERENCES}

1. Acharya, A., M.L. Sharma, K. Bishwakarma, P. Dahal, S. Kumar, Chaudhari, B. Adhikari, S. Neupane, B.N. Pokhrel and R.R. Pant. 2020. Chemical Characteristics of the Karmanasha River Water and Its Appropriateness for Irrigational Usage. Journal of Nepal Chemical Society, 41(June), 94-102. https://doi.org/10.3126/ jncs.v41i1.30494

2. Adhikari, B., R.R. Pant, U. Baral, S. Shrestha, S. Neupane, B. Khanal, A. Acharya and H. Bhattarai. 2020. Geochemical and multivariate assessment of water quality in the Rajarani Lake, Dhankuta, Nepal. Journal of Nepal Geological Society, 60, 37-49. https:// doi.org/https://doi.org/10.3/26/jngs.v60i0.31264

3. APHA. 2005. Standard Methods for the Examination of Water and Wastewater. 21st ed. American Public Health Association, Washington DC. Standard Methods for the Examination of Water and Wastewater. 21st Ed. American Public Health Association, Washington DC., 1220 .

4. Ayers, R. S. \& D.W. Westcot. 1985. Water Quality for Agriculture. In FAO of the UNITED NATIONS, Rome, Italy.

5. Bhatta, R., S. Tuladhar, S. Gurung \& N. Raut. 2020. Water quality of Ghodaghodi Lake : a Ramsar site in western Nepal. NRACC 2019, 1-6.

6. Bishwakarma, K., R.R. Pant, K.B. Pal, A. Ghimire, L.B. Thapa, P. Saud, S. Joshi and K.P. Panthi. 2019. Water quality and land use/cover changes in the Phewa Watershed, Gandaki Province, Nepal. Nepal J. Environ. Sci. 7, 31-39. https://doi.org/ 10.3126/njes.v7i0.34473

7. Chen, J., F. Wang, X. Xia and L. Zhang. 2002. Major element chemistry of the Changjiang (Yangtze River). Chemical Geology, 187(3-4), 231-255. https://doi. org/10.1016/S0009-2541(02)00032-3

8. Das, B.K. 2005. Environmental pollution impact on water and sediments of Kumaun lakes, Lesser Himalaya, India: A comparative study. Environmental Geology, 49(2), 230-239. https://doi.org/10.1007/ s00254-005-0077-0

9. EPA, U. 1989. Carcinogen risk assessment. 
Environmental Health Perspectives, 81, 103-105. https://doi.org/ 10.1289/ ehp.8981103

10. Filzmoser, P., K. Hron \& C. Reimann. 2009. Principal component analysis for compositional data with outliers. Environmetrics, 20(6), 621-632. https://doi. org/10.1002/env.966

11. Gibbs, R.J. 1970. Mechanisms controlling world water chemistry. Science, 170(3962), 1088-1090. https://doi. org/10.1126/ science.170.3962.1088

12. Gautam, B., R. Maskey, R.P. Sapkota and D.R. Dangol. 2015. Aquatic Macro-invertebrates as Bio-indicators: An Approach for Wetland Water Quality Assessment of Rampur Ghol, Chitwan, Nepal. Journal of Institute of Science and Technology, 19(2), 58-64. https://doi. org/10.3126/jist.v19i2.13853

13.Khadka, U.R., and A.L. Ramanathan. 2013. Major ion composition and seasonal variation in the Lesser Himalayan lake: Case of Begnas Lake of the Pokhara Valley, Nepal. Arabian Journal of Geosciences, 6(11), 4191-4206. https://doi.org/ 10.1007/s12517-012$0677-4$

14. Lamsal, P., K.P. Pant, L. Kumar \& K. Atreya. 2014. Diversity, Uses, and Threats in the Ghodaghodi Lake Complex, a Ramsar Site in Western Lowland Nepal. ISRN Biodiversity, 2014, 1-12. https://doi. org/10.1155/2014/680102

15.Li, S., \& Q. Zhang. 2010. Spatial characterization of dissolved trace elements and heavy metals in the upper Han River (China) using multivariate statistical techniques. Journal of Hazardous Materials, 176(1-3), 579-588. https://doi.org/ 10.1016/j. jhazmat.2009.11.069

16. Meybeck, M. and R. Helmer. 1989. The quality of rivers: From pristine stage to global pollution. Paleogeography, 75(4), 283-309. https://doi. org/10.1016/0031-0182(89)90191-0

17. Pal, K.B., R.R. Pant, B. Rimal, A.D. Mishra. 2019. Comparative Assessment of Water Quality in the Bagmati River Basin, Nepal. ZOO-Journal, 5(December), 68-78.

18. Pal, K.B., K. Bishwakarma, T.B. Chalaune, D. Upadhaya, T.R. Joshi, L.B. Thapa, M.L. Sharma, S. Joshi and R.R. Pant. 2021. Hydrochemical assessment of Jhilmila Lake, Kanchanpur, Nepal. Scientific World, 14(14), 124-131. https://doi.org/10.3126/ sw.v14i14.35023
19. Pant, R.R. and N.L. Adhikari. 2015. Water Quality Assessment of Phewa Lake, Pokhara Nepal. Cognition-A Transdisciplinary Research Journal, 1(June), 130-140.

20. Pant, R.R., K.B. Pal, N.L. Adhikari, S. Adhikari and A.D. Mishra 2019. Water Quality Assessment of Begnas and Rupa Lakes, Lesser Himalaya Pokhara, Nepal. Journal of the Institute of Engineering, 15(2), 113-122. https://doi.org/10.3126/ jie.v15i2.27655

21. Pant, R.R, F. Zhang, F.U. Rehman, G. Wang, M. Ye, C. Zeng and H. Tang. 2018. Spatiotemporal variations of hydrogeochemistry and its controlling factors in the Gandaki River Basin, Central Himalaya Nepal. Science of the Total Environment, 622-623(January 2018), 770 782. https://doi.org/10.1016/j.scitotenv.2017.12.063

22. Pant, R.R. 2013. Water Quality Assessment of Nagdaha Lake, Lalitpur, Nepal. Journal of TUTA University Campus, 8(November), 52-56.

23. Pant, R.R., K. Bishwakarma, F.U.R. Qaiser, L. Pathak, G. Jayaswal, B. Sapkota, K.B. Pal, L.B. Thapa, M. Koirala, K. Rijal and R. Maskey. 2021a. Imprints of COVID-19 lockdown on the surface water quality of Bagmati river basin, Nepal. Journal of Environmental Management, 289(112522), 1-13. https://doi. org/10.1016/j.jenvman.2021.112522

24. Pant, R.R., K. Bishwakarma, B.B. Basnet, K.B. Pal, L. Karki, Y.P. Dhital, Y.R. Bhatta, B.R. Pant and L.B. Thapa. 2021b. Distribution and risk appraisal of dissolved trace elements in Begnas Lake and Rupa Lake, Gandaki Province, Nepal. SN Applied Sciences, 3(532), 1-13. https://doi.org/10.1007/s42452-02104516-5

25. Piper. 1944. A Graphic Producer in the Geochemical Interpretation of Water Analysis. American Geophysical Union, 914-928.

26. Rehman Qaisar, F.U., F. Zhang, R.R. Pant, G. Wang, S. Khan and C. Zeng. 2018. Spatial variation, source identification, and quality assessment of surface water geochemical composition in the Indus River Basin, Pakistan. Environmental Science and Pollution Research, 25(13), 12749-12763. https://doi. org/10.1007/s11356-018-1519-z

27. Rupakheti, D., L. Tripathee, S. Kang, C.M. Sharma, R. Paudyal and M. Sillanpää. 2017. Assessment of water quality and health risks for toxic trace elements in urban Phewa and remote Gosainkunda lakes, Nepal. 
Human and Ecological Risk Assessment, 23(5), 959973. https://doi.org/10.1080/10807039.2017.1292117

28. Sajil Kumar, P.J. 2016. Deciphering the groundwatersaline water interaction in a complex coastal aquifer in South India using statistical and hydrochemical mixing models. Modeling Earth Systems and Environment, 2(4), 1-11. https://doi.org/ 10.1007/s40808-016-02512

19. Sharma, C., S. Kang and L. Tripathee. 2020. Major ions and irrigation water quality assessment of the Nepalese Himalayan rivers. Environment, Development, and Sustainability, 0123456789. https://doi.org/10.1007/ s10668-020-00694-1

30. Singh, K.P., A. Malik, D. Mohan and S. Sinha. 2004. Multivariate statistical techniques for the evaluation of spatial and temporal variations in water quality of Gomti River (India) - A case study. Water Research, 38(18), 3980-3992. https://doi.org/10.1016/j. watres.2004.06.011

31. Singh, V.B., A.L. Ramanathan and A. Mandal. 2016. Hydrogeochemistry of high-altitude lake: a case study of the Chandra Tal, Western Himalaya, India. Arabian Journal of Geosciences, 9(4), 1-9. https://doi. org/10.1007/s12517-016-2358-1
32. Subedi, R., D. Bhuju, G. Bhatta and R. Pant. 2018. Climate variability and livelihood of rural farmers in Chisapani, Ramechhap, Nepal. Nepal Journal of Environmental Science.

33. Varol, M., B. Gökot, A. Bekleyen and B. Şen. 2013. Geochemistry of the Tigris River basin, Turkey: Spatial and seasonal variations of major ion compositions and their controlling factors. Quaternary International, 304(August), 22-32. https://doi.org/10.1016/j. quaint.2012.12.043

34. WHO. 2011. Guidelines for Drinking-water Quality.

35. Zhang, F., S. Thapa, W. Immerzeel, H. Zhang and A. Lutz. 2019. Water availability on the Third Pole: A review. Water Security, 7(March). https://doi. org/10.1016/j.wasec.2019.100033 